\title{
Effect of Varying Levels of Moringa Olifera Leaf Meal on Performance and Blood Profile of Weaner Rabbits
}

\author{
Olatunji A. K ${ }^{1}$, O. J Alagbe ${ }^{2}$, Hammed M. A ${ }^{3}$
}

\begin{abstract}
Forty five, 5-8week old growing rabbits of mixed breed and sex were used in an experiment to evaluate the effect of varying levels of Moring a leaf meal on the performance, nutrient digestibility and blood profile of rabbits. The rabbits were randomly assigned to five treatment group in a Completely Randomized Design (CRD) and each treatment was further sub-divided into three replicates. The rabbits were fed growers ration supplemented with Moringa leaf meal at levels of $0 \%, 5 \%, 10 \%, 15 \%$ and $20 \%$ representing treatments 1,2,3,4 and 5 respectively. Performance criteria were feed intake, final weight gain and nutrient digestibility while the blood profile include hematological and serum analysis. The result reveals that all the heamatological parameters ( Red blood cell, White blood cell, Mean corpuscular haemoglobin, Mean corpuscular haemoglobin concentration \& Mean corpuscular volume) and Serum biochemical indices (Albumin, Globulin, Total protein, Alkaline phosphatase, Serum glutamic oxaloacetate transaminase \& Serum glutamic pyruvic transaminase) were not significantly (P>0.05) affected as the level of Moringa leaf meal increased. The results of this experiment demonstrated that the inclusion of Moringa leaf meal at up to $20 \%$ has no deleterious effect on growth, performance and health status of weaner rabbits.
\end{abstract}

Keywords: weaner rabbit, performance, moringa leaf meal, health status

\section{Introduction}

The inadequate supply and intake of animal protein in developing countries is high due to high cost of feeding with the accompanying high cost of production (Onu et al., 2004), one of the ways of reducing the cost of production and making protein available to people at a cheaper prices is by the use of agricultural by-products and tropical plants which are not directly used by humans as food to feed livestock (Asar et al., 2010)

Rabbit plays a vital role in the utilization of fibrous by products which can be converted into animal protein for human consumption. They are selective feeders and therefore palatability of forages is very important, many forages and plants can be used for feeding rabbits one of such is Moringa olifera.

Moringa olifera commonly known as drumstick-tree or horse radish tree is a multi-purpose that has given considerable fodder yield in the tropical humid forest zone of Nigeria during the wet and dry seasons (Fadyimu et al., 2011). According to Siddhuraju et al (2003) moringa olifera have been identified to contain natural antioxidants. The leaves can serve as a rich source of $\beta$ - carotene $e_{x}$ vitamin $\mathrm{C}$ and $\mathrm{E}$ and polyphenolics and it contains up to $25 \%$ crude protein ( Makkar et al., 1996).

This study is designed to investigate the feeding varying levels of moringa leaf meal on the performance and blood profile of weaner rabbits.

\section{Materials and Methods}

\section{Location of the experiment}

The experiment was carried out at the Demola Acres Research Centre along Airport Road, Kutungare. Kaduna, Nigeria Animals and their management
Forty five, 5-8 weeks old weaner rabbits of mixed breed and sex with a weight range of between $607-615 \mathrm{~g}$ were randomly assigned to five dietary groups of ten rabbits per group in a completely randomized design. The rabbits were acclimatized for 2 weeks, after which they were individually housed in an all wire metabolic cages with provision of drinking and water troughs. Water were offered unrestricted, feed was also supplied.

Feed intake was determined from the daily feed left over, and recorded daily. Live weight was recorded on a weekly basis throughout the experiment which lasted for 60days.

\section{Preparation of experimental diets}

Moringa leaves were air dried on a concrete floor in a shed. The dried leaves are then hammer milled to produce Moringa leaf meal (MLM).

The test ingredient (MLM) were mixed together with other materials to form five experimental diets at levels $0,5,10,15$ and $20 \%$ as presented in Table 1 . The Chemical composition of Moringa leaf meal is presented in Table 2.

\section{Blood Analysis}

At the end of $8^{\text {th }}$ week of the experiment, eight rabbits were randomly selected per treatment, starved of feed overnight but not water. From the selected rabbit's blood samples was collected $\mathrm{f}$ via the marginal vein with a $10 \mathrm{ml}$ syringe.

All the blood samples for hematological indices were collected into bottles containing EDTA, as anti-coagulant. The haematological indices determined included Pack cell volume (PCV), Haemoglobin concentration $(\mathrm{Hb})$, White blood cell count (WBC), Red blood cell count (RBC), Mean corpuscular haemoglobin $(\mathrm{MCH})$, Mean corpuscular haemoglobin concentration (MCHC), Mean corpuscular volume (MCV) and White blood differential counts (i.e. Lymphocyte, Monocytes, Neutrophils and Eosinophils) was determined by micro-haematocrit method. 


\section{International Journal of Science and Research (IJSR) \\ ISSN (Online): 2319-7064 \\ Index Copernicus Value (2013): 6.14 | Impact Factor (2015): 6.391}

For serum biochemistry, the following were determined; total serum protein, serum albumin, serum globulin, serum glutamic pyruvate transaminase, serum glutamic oxaloacetate transaminase, alkaline phosphatase.

\section{Digestibility Trial}

At the last week of the experiment, ten rabbits were selected from each treatment, manure collection trays were provided in the cages where the rabbits were housed. The total daily feed consumed and the manure voided was recorded daily, throughout the period of the digestibility trail which lasted for 7 days.

\section{Chemical Analysis}

The proximate components of the Moringa leaf were determined by the A.O.A.C (1990).

\section{Statistical Analysis}

All data collected were subjected to analysis of variance (ANOVA) using SAS, (2005) and significant means separated by Duncan multiple range test (Duncan, 1955).

Table 1: Percentage Composition of the Experimental Diets

\begin{tabular}{|l|c|c|c|c|c|}
\hline Ingredients & 1 & 2 & 3 & 4 & 5 \\
\hline & 19.00 & 19.00 & 19.00 & 19.00 & 19.00 \\
\hline Maize & 34.00 & 34.00 & 34.00 & 34.00 & 34.00 \\
\hline Wheat offal & 10.00 & 10.00 & 10.00 & 10.00 & 10.00 \\
\hline Soyameal & 32.00 & 32.00 & 32.00 & 32.00 & 32.00 \\
\hline Palm kernel cake & 2.00 & 2.00 & 2.00 & 2.00 & 2.00 \\
\hline Groundnut cake & 2.00 & 2.00 & 2.00 & 2.00 & 2.00 \\
\hline DCP & 0.12 & 0.12 & 0.12 & 0.12 & 0.12 \\
\hline Lysine & 0.13 & 0.13 & 0.13 & 0.13 & 0.13 \\
\hline Methionine & 0.25 & 0.25 & 0.25 & 0.25 & 0.25 \\
\hline Premix & 0.50 & 0.50 & 0.50 & 0.50 & 0.50 \\
\hline Salt & 0 & 5 & 10 & 15 & 20 \\
\hline Moringaleaf meal & 100 & 100 & 100 & 100 & 100 \\
\hline \multicolumn{5}{|l|}{} \\
\hline Determined Analysis & 17.02 & 17.11 & 17.27 & 17.32 & 17.36 \\
\hline Crude protein (\%) & 9.56 & 9.56 & 9.56 & 9.56 & 9.56 \\
\hline Crude fibre (\%) & 2980 & 2983 & 2986 & 2988 & 2999 \\
\hline Digestible Energy (Kcal/kg) & 298 &
\end{tabular}

Table 2: Chemical Composition of Moringa Leaf Meal (MLM)

\begin{tabular}{|l|c|}
\hline Nutrients & $\%$ DM \\
\hline Crude Protein & 27.89 \\
\hline CrudeFibre & 19.12 \\
\hline Ether extracts & 2.67 \\
\hline Ash & 8.17 \\
\hline Nitrogen free extracts & 42.33 \\
\hline Phosphorus & 0.45 \\
\hline Calcium & 9.02 \\
\hline
\end{tabular}

Table 3: Performance and Hematological traits of rabbits fed varying levels of MLM

Diets

\begin{tabular}{|l|c|c|c|c|c|c|}
\hline Parameters & 1 & 2 & 3 & 4 & 5 & S/L \\
\hline Initial live wgt (g) & $607.2 \pm 31.3$ & $610.6 \pm 51.2$ & $611.5 \pm 59.6$ & $615.0 \pm 66.7$ & $615.0 \pm 30.6$ & NS \\
\hline Final live wgt (g) & $1520.1 \pm 33.4$ & $1561 \pm 51.4$ & $1571.1 \pm 49.1$ & $1591.1 \pm 56.2$ & $1575 \pm 20.9$ & NS \\
\hline Pack cell vol. $(\%)$ & $42.4 \pm 3.71$ & $43.30 \pm 4.51$ & $46.11 \pm 1.84$ & $45.20 \pm 2.59$ & $46.34 \pm 0.43$ & NS \\
\hline RBC $(\times 10 \mathrm{~mm} 3)$ & $7.10 \pm 0.44$ & $7.23 \pm 0.76$ & $7.40 \pm 0.90$ & $7.43 \pm 0.87$ & $7.52 \pm 0.89$ & NS \\
\hline WBC $(\times 10 \mathrm{~mm} 3)$ & $8.10 \pm 0.77$ & $8.23 \pm 0.56$ & $8.43 \pm 0.30$ & $8.45 \pm 0.50$ & $8.49 \pm 0.59$ & NS \\
\hline MCV $(\mathrm{Fl})$ & $61.9 \pm 1.30$ & $61.2 \pm 0.56$ & $61.6 \pm 0.34$ & $60.9 \pm 045$ & $61.3 \pm 0.77$ & NS \\
\hline $\mathrm{MCH}(\mathrm{Pg})$ & $17.9 \pm 0.25$ & $17.6 \pm 0.40$ & $17.8 \pm 0.35$ & $17.5 \pm 0.02$ & $17.1 \pm 0.76$ & $\mathrm{NS}$ \\
\hline $\mathrm{MCHC}(\mathrm{g} / \mathrm{dl})$ & $31.9 \pm 0.89$ & $31.1 \pm 0.22$ & $31.5 \pm 0.15$ & $31.3 \pm 0.20$ & $31.4 \pm 0.03$ & $\mathrm{NS}$ \\
\hline Neutrophils $(\%)$ & $45.0 \pm 1.32$ & $43.7 \pm 0.77$ & $44.3 \pm 0.69$ & $44.9 \pm 0.35$ & $44.2 \pm 1.56$ & $\mathrm{NS}$ \\
\hline Lymphocytes(\%) & $57.2 \pm 2.65$ & $51.8 \pm 1.87$ & $55.3 \pm 1.43$ & $52.7 \pm 1.80$ & $50.4 \pm 3.12$ & $\mathrm{NS}$ \\
\hline Monocytes $(\%)$ & $1.10 \pm 0.21$ & $1.30 \pm 0.38$ & $1.29 \pm 0.35$ & $1.17 \pm 0.33$ & $1.34 \pm 0.31$ & $\mathrm{NS}$ \\
\hline Eosinophils (\%) & $1.05 \pm 0.04$ & $1.03 \pm 0.68$ & $1.01 \pm 0.02$ & $1.02 \pm 0.68$ & $1.09 \pm 0.89$ & $\mathrm{NS}$ \\
\hline
\end{tabular}

Volume 5 Issue 6, June 2016 www.ijsr.net

Licensed Under Creative Commons Attribution CC BY 


\section{International Journal of Science and Research (IJSR) \\ ISSN (Online): 2319-7064}

Index Copernicus Value (2013): 6.14 | Impact Factor (2015): 6.391

Table 4: Serum biochemical parameters of rabbits fed varying level of MLM

\begin{tabular}{|l|l|c|c|c|c|c|}
\hline Parameter & 1 & 2 & 3 & 4 & 5 & $\mathrm{~S} / \mathrm{L}$ \\
\hline Albumin $(\mathrm{g} / \mathrm{dl})$ & $2.97 \pm 0.15$ & $3.00 \pm 0.13$ & $3.12 \pm 0.09$ & $3.15 \pm 0.07$ & $3.18 \pm 1.10$ & NS \\
\hline Globulin $(\mathrm{g} / \mathrm{dl})$ & $2.40 \pm 0.08$ & $2.30 \pm 0.04$ & $2.37 \pm 0.06$ & $2.14 \pm 0.03$ & $2.02 \pm 0.09$ & NS \\
\hline Total protein $(\mathrm{g} / \mathrm{dl})$ & $5.37 \pm 0.19$ & $5.30 \pm 0.12$ & $5.49 \pm 0.10$ & $5.29 \pm 0.07$ & $5.20 \pm 0.85$ & NS \\
\hline SGOT $(\mathrm{u} / \mathrm{l})$ & $7.97 \pm 0.88$ & $7.81 \pm 0.87$ & $7.88 \pm 0.57$ & $7.90 \pm 0.39$ & $7.86 \pm 0.28$ & NS \\
\hline SGPT $(\mathrm{u} / \mathrm{l})$ & $17.45 \pm 1.34$ & $16.79 \pm 1.0$ & $16.45 \pm 1.25$ & $17.02 \pm 1.33$ & $17.43 \pm 1.15$ & NS \\
\hline ALP $(\mathrm{u} / \mathrm{l})$ & $40.1 \pm 1.15$ & $39.84 \pm 1.60$ & $39.00 \pm 1.12$ & $40.70 \pm 0.56$ & $39.88 \pm 1.23$ & NS \\
\hline
\end{tabular}

SGOT $=$ Serum glutamic oxaloacetate transaminase

SGPT = Serum glutamic pyruvate transaminase

ALP $=$ Alkaline phosphatase

$\mathrm{NS}=$ No significant difference $(\mathrm{P}>0.05)$

Table 5: Apparent nutrient digestibility of rabbits fed Moringa leaf meal diets

\begin{tabular}{|l|l|l|l|l|l|c|}
\hline Parameters & \multicolumn{1}{|c|}{1} & \multicolumn{1}{c|}{2} & \multicolumn{1}{c|}{3} & \multicolumn{1}{c|}{4} & \multicolumn{1}{c|}{5} & S/L \\
\hline Dry matter (DM) & $56.10 \pm 1.88$ & $71.02 \pm 2.10$ & $73.0 \pm 3.12$ & $78.12 \pm 1.23$ & $80.7 \pm 1.28$ & $*$ \\
Crude Protein (CP) & $65.13 \pm 2.30$ & $76.0 \pm 1.56$ & $79.3 \pm 4.50$ & $83.7 \pm 1.97$ & $89.2 \pm 2.13$ & $*$ \\
Crude fibre (CF) & $50.18 \pm 1.50$ & $51.2 \pm 2.30$ & $53.8 \pm 0.90$ & $54.1 \pm 1.34$ & $56.2 \pm 2.00$ & NS \\
Ether extracts (EE) & $71.20 \pm 3.12$ & $72.30 \pm 1.88$ & $73.51 \pm 1.89$ & $75.19 \pm 3.90$ & $77.2 \pm 3.71$ & NS \\
\hline
\end{tabular}

$\mathrm{NS}=$ No significant difference $(\mathrm{P}>0.05)$

*= Significantly different $(\mathrm{P}<0.05)$

\section{Results}

Table 2 shows the chemical composition of Moringa leaf meal. The proximate components contains $27.89 \%, 19.12 \%$, $2.67 \%, 8.17 \%, 42.33 \%, 0.45 \%$ and $9.02 \%$ of crude protein, crude fibre, ether extract, ash, nitrogen free extract, phosphorus and calcium respectively.

Table 3. Shows the growth performance and the values of hematological indices investigated, the rabbit final live weight ranges between $1520.1 \mathrm{~g}$ and $1575.0 \mathrm{~g}$, the data shows that there is no significant difference $(\mathrm{P}>0.05)$ among the treatment in terms of their final live weight.

The Pack cell volume values obtained are 42.4, 43.3, 46.1, 45.2 and $46.3 \%$ for diets $1,2,3,4$ and 5 respectively. While those of Red blood cells are 7.10, 7.23, 7.40, 7.43 and 7.52 $(\times 10 \mathrm{~mm} 3)$ for diets $1,2,3,4$ and 5 .

Pack cell volume (PCV), Red blood cell (RBC), Mean corpuscular volume (MCV), Mean corpuscular haemoglobin $(\mathrm{MCH})$ and Mean corpuscular haemoglobin concentration $(\mathrm{MCHC})$ were not significantly affected $(\mathrm{P}>0.05)$ with the dietary inclusion of Moringa leaf meal (MLM). The red blood cell values marginally increased from diet 1 to 5 .

The White blood cell (WBC) values obtained are 8.10, 8.23, $8.43,8.45$ and $8.49(\times 10 \mathrm{~mm} 3)$ for diets $1,2,3,4$ and 5 respectively. From the records, the WBC, lymphocytes, Monocytes, Neutrophils and Eosinophils were not significantly $(\mathrm{P}>0.05)$ influenced by the different inclusion of Moringa leaf meal.

Table 4 reveals the serum biochemical parameters of rabbits as influenced by the diets, the Albumin values are 2.97, $3.00,3.12,3.15$ and $3.18 \mathrm{~g} / \mathrm{dl}$ for diets $1,2,34$ and 5 respectively, while those of Globulin are 2.40, 2.30, 2.37, 2.14 and $2.02 \mathrm{~g} / \mathrm{dl}$ for diets $1,2,3,4$ and 5 . The values obtained for Total protein in $\mathrm{g} / \mathrm{dl}$ are 5.37, 5.30, 5.49, 5.29 and 5.20 for diets 1,2,3,4 and 5 respectively.

Albumin, Globulin, Total protein, SGPT, SGOT and ALP were not significantly affected $(\mathrm{P}>0.05)$ by the dietary inclusion of Moringa leaf meal (MLM) across the treatment.

The Apparent nutrient digestibilities as influenced by the diets are presented in Table 5. Dry matter values obtained are $56.10,71.02,73.00,78.12$ and $80.70 \%$ for diets $1,2,3,4$ and 5 respectively while Crude protein values are 65.13, $76.00,79.30,83.70$ and $89.20 \%$ for diets $1,2,3,4$ and 5 respectively. The values obtained for crude fibre $(\mathrm{CF})$ in $\%$ are $50.18,51.20,53.80,54.10$ and 56.20 for diets $1,2,3,4$ and 5 respectively.

Dry matter (DM) and Crude protein (CP) levels were significantly $(\mathrm{P}<0.05)$ influenced by the different inclusion levels of Moringa leaf meal, the DM and $\mathrm{CP}$ values marginally increased from diets 1 to 5. The CF and Ether extract were not significantly $(\mathrm{P}>0.05)$ affected with an increase in the level of Moringa leaf meal across the treatment.

\section{Discussion}

The crude protein in the experimental diets increased as the inclusion of Moringa leaf meal increases, however, there was no significant difference $(\mathrm{P}>0.05)$ in the final live weight. This implies that the inclusion level of MLM across the treatment is adequately enough to support the growth and development of the rabbits. Rabbits fed diet 5 had a better final weight, this could be due to higher protein content in the feed which agrees with the findings of Odetola et al. (2012)

\section{Volume 5 Issue 6, June 2016 www.ijsr.net}




\section{International Journal of Science and Research (IJSR) \\ ISSN (Online): 2319-7064}

Index Copernicus Value (2013): 6.14 | Impact Factor (2015): 6.391

The Red blood cell values were not significantly $(\mathrm{P}>0.05)$ influenced with the inclusion of Moringa leaf meal, this means that shows that oxygen and carbon dioxide are well distributed in the body to enhance respiration and good health status. The values recorded fall within the normal recorded by Mitruka and Rawnsley (1977) and it agrees with findings of Odetola et al. (2012).

The Pack cell volume (PCV), MCV, MCH, MCHC, Neutrophils, Lymphocytes , Monocytes and Eisinophils were not significantly affected $(\mathrm{P}>0.05)$ with the inclusion of Moringa leaf meal. The value of PCV indicates a proper nutrient absorption within the system of the animal. This report agrees with the findings of Olabanji et al. (2007), when rabbits were fed Wild sunflower meal and the normal range established by Mitruka and Rawnsley (1977).

The WBC values were not significantly $(\mathrm{P}>0.05)$ affected with the inclusion of MLM, but there was a marginal increase in values from diet 1-5, this implies that the immune system of the rabbit is adequate because of the presence of antibodies. According to Soetan et al. (2013) high counts of WBC enhance adaptability to local environment and disease prevalent conditions.

The serum total protein, albumin and globulin of the rabbits used in this study were not significantly affected $(\mathrm{P}>0.05)$, it simply shows that the protein content in the experimental diet is enough to support the animals tissues, Similarly SGOT and SGPT were not significantly influenced by different inclusion of MLM which is an indication that the rabbits were able to tolerate the anti-nutrient present in the leaf meal.

\section{Conclusion}

Most of the parameters tested viz growth, heamatological and serum analysis showed no significant difference, it could therefore be concluded that the inclusion of Moringa leaf meal at $20 \%$ has no deleterious effect on the performance, growth and health status of rabbits.

\section{References}

[1] Asar et al. (2010). Utilization of corn-cob meal and faba bean straw in growing rabbits diets and their performance, digestibility and economical efficiency. Egypt Poultry Science. 2010; 30:415-442.

[2] Aja et al. (2014). Chemical constituents of Moringa oleifera leaves and seeds from Abakaliki, Nigeria. American Journal of Phytomedcine and Clinical Therapeutics. AJPCT [2] [3] [2014] 310-321.

[3] AOAC, (1990). Association of Official Analytical Chemist Official Methods of Analysis $15^{\text {th }}$ Edition.

[4] Duncan, D.B (1955). Multiple range and multiple Ftests. Biometrics, 11:1-42

[5] Fadiyimu, A.A., Fajeminsin, A.N., Alokan, J. A and Aladesanwa, R.D. (2011) Effect of cutting regimes on seasonal fodder yield of Moringa oleifera in the tropical rain forest of Nigeria. Livestock Research for Rural Development. 23(2).
[6] Makkar, H.P.S and Goodchild, A.V. (1996) Quantification of tannins, a laboratory manual. International for Agricultural Research 128:311-322.

[7] Mitruka, B. M., Rawnsley, H.M (1977). Clinical biochemical and hematological reference values in normal experimental animals (p.134-135). USA: Masson Publishing Inc.

[8] Onu et al. (2004). Effect of graded levels of dietary penicillin on the growth rate and feed conversion of broiler chicks. Journal of Agriculture and Social Research vol 4 No 2, 2004.

[9] Olabanji et al. (2007). Studies on haematological and biochemical characteristics of weaner rabbits fed different levels of wild sunflower leaf (Tithonia diversifolia Hemsl. Gray) leaf - blood meal mixture vol 4 Numbers $1 \& 2$

[10] Soetan et al. (2013). Preliminary studies on the hematological parameters of cockerels fed raw and processed guinea corn (Sorghum bicolor) (p.49-52) Proceedings of $38^{\text {th }}$ Annual Conference of Nigerian Society for Animal production.

[11] Siddhuraju, P and K. Becker (2003). Antioxidant properties of various solvents extracts of total phenolic constituents from three different agro climatic origins of drumsticks tree (Moringa olifera Lam.) leaves. Journal of agriculture and food chem., 51:2144-2155. 